\title{
A New Blind Underground Species of the Genus Protocobitis (Cobitidae) from Guangxi, China
}

\author{
ZHU Yu ${ }^{1}$, LÜ Ye-jian ${ }^{2}$, YANG Jun-xing ${ }^{3,}$, ZHANG Sheng ${ }^{2}$ \\ (1. Fishery and Animal Husbandry School of Guangxi, Nanning 530021, China;2. Guangxi Fishery Experimental Farm, Nanning \\ 530031, China;3. Kunming Institute of Zoology, the Chinese Academy of Sciences, Kunming 650223, China)
}

\begin{abstract}
A new species of the genus Protocobitis, was discovered in an underground water source (110m depth) located about $5 \mathrm{~km}$ away from the county town of Wuming, Guangxi, China, in May 2006. The new species, Protocobitis polylepis sp. nov., is distinguished from the single congener by the following characteristics: 1) light black pigmentation present vs. no pigmentation; 2) entire body covered with scales except for its head and abdomen vs. rudimentary scales present only along the midline of the body; 3) head length $24.1 \%-24.8 \%$ of SL vs. $19.8 \%-22.1 \%$ of SL; 4) body depth $16.2 \%-16.3 \%$ of SL vs. $11.5 \%-13.0 \%$ of SL; 5) Inner rostral barbel length $19.8 \%-21.0 \%$ of head length vs. $9.4 \%-11.8 \%$ of head length; outer rostral barbel length $28.6 \%-30.2 \%$ of head length vs. $15.3 \%-21.8 \%$ of head length; maxillary barbell length $44.6 \%-46.0 \%$ of head length vs. $22.4 \%-31.8 \%$ of head length.
\end{abstract}

Key words: Protocobitis; New species; Guangxi

\section{中国广西原花鱾属穴居盲鱼一新种一一多鳞原花鳅 \\ 朱 瑜 ${ }^{1}$, 吕业坚 ${ }^{2}$, 杨君兴 ${ }^{3, *}$, 张 盛 ${ }^{2}$ \\ (1. 广西水产畜牧学校, 广西 南宁 530021; 2. 广西水产试验场, 广西 南宁 530031; \\ 3. 中国科学院昆明动物研究所, 云南 昆明 650223)}

\begin{abstract}
摘要: 2006 年 5 月从广西武鸣县城 $5 \mathrm{~km}$ 的地下龙潭中发现了原花鳅属的一个新种。该新种被命名为多鳞原花 鳅(Protocobitis polylepis), 与该属唯一已知种无眼原花鳅(Protocobitis typhlops)的鉴别特征如下: 1) 体背和体侧具 淡的色素 vs.色素完全退化；2）除头和腹部外身体其余部分被稀疏鳞片 vs.稀疏鳞片仅见于体侧中线; 头长为体长 $24.1 \%-24.8 \%$ vs. $19.8 \%-22.1 \%$; 体高为体长 $16.2 \%-16.3 \%$ vs. $11.5 \%-13.0 \%$; 内侧吻须长为头长 $19.8 \%-21.0 \%$ vs. $9.4 \%-11.8 \%$; 外侧吻须长为头长 $28.6 \%-30.2 \%$ vs. $15.3 \%-21.8 \%$; 领须长为头长 $44.6 \%-46.0 \%$ vs. $22.4 \%-$ $31.8 \%$ 。
\end{abstract}

关键词: 原花鳅; 新种; 广西

中图分类号: Q959.4 文献标识码: A 文章编号: 0254-5853-(2008)04-0452-03

The loach Protocobitis occurs only in Guangxi, China (Yang, 1994). The genus is characterized by the following characteristics: bony bladder capsule absent, parapophysis of the 4 th vertebra forming simple rib-like bone; rib absent, each vertebrae having only short and simple parapophysis; posterior margin of pharyngeal process truncated; first branched ray of pectoral fin in male slightly elongated without any flap-like projection on dorsal side of pectoral fin; dorsal fin origin in advance of pelvic fin origin. Only one species in the genus, $P$. typhlops has been known (Yang, 1994). In May 2006, we collected two blind loach specimens from an underground water source located about $5 \mathrm{~km}$ away from the county town of Wuming, Guangxi. The two specimens were identified as new species of the genus Protocobitis.

\section{Materials and Method}

Counts and measurements follow Chu \& Chen (1989) Measurements were made with dial callipers and recorded to the nearest $0.1 \mathrm{~mm}$. The examined specimens of Protocobitis typhlops belonged to the collections at

Received date:2008-05-19; Accepted date: 2008-06-04

“Corresponding author(通讯作者), E-mail: yangjx@mail.kiz.ac.cn

收稿日期：2008-05-19; 接受日期：2008-06-04 
the Kunming Institute of Zoology (KIZ), the Chinese Academy of Sciences. Abbreviations used in the this paper are: D, number of dorsal-fin ray; A, number of anal-fin rays; $\mathrm{P}$, number of pectoral-fin rays; $\mathrm{V}$, number of pelvic-fin rays, $\mathrm{C}$, number of branched caudal-fin rays and SL, standard length.

\section{Results and Discussion}

\subsection{Protocobitis polylepis sp. nov.}

Holotype. KIZ20060001, female, $33.0 \mathrm{~mm}$ SL; Guangxi: Wuming Co: from an underground water source near the county town; Zhang Sheng, May 2006.

Paratype. KIZ20060002, male, 1 ex. $26.1 \mathrm{~mm}$ SL; same data as holotype.

Diagnosis. Protocobitis polylepis can be distinguished from the known species, Protocobitis typhlops, by the following characteristics: light black pigmentation present; body covered by rudimental scales except for head and abdomen; head length 24.1\%-24.8\% of SL; body depth $16.2 \%-16.3 \%$ of SL; inner rostal barbel length $19.8 \%-21.0 \%$ of head length; outer rostal barbel length $28.6 \%-30.2 \%$ of head length; maxillary barbel length $44.6 \%-46.0 \%$ of head length. Comparisons of characteristics between $P$. polylepis and P. typhlops are shown in Tab. 1.

Description. D.2/6-7; A.2/5; P.1/7; V. 1/4. Gill-

Tab. 1 Comparisons of characteristics between Protocobitis polylepis and P. typhlops

\begin{tabular}{lll}
\hline \multicolumn{1}{c}{ Characteristics } & \multicolumn{1}{c}{ P. polylepis sp. nov. } & \multicolumn{1}{c}{ P. typhlops } \\
\hline $\begin{array}{l}\text { No. of specimens } \\
\text { Body length }\end{array}$ & 2 & 6 \\
Locality & $26.1-33.0$ & $39.0-54.0$ \\
Collecting date & Wuming Co. & Xiaao town of Duan Co. \\
Black pigmentation & May of 2006 & Aug. of 1991 \\
Scales & present & absent \\
& scaled except for head and abdomen & rudimentary scales present only \\
Head length & & along midline of body \\
Body depth & $24.1 \%-24.8 \%$ of SL & $19.8 \%-22.1 \%$ of SL \\
Inner rostral barbel length & $16.2 \%-16.3 \%$ of SL & $11.5 \%-13.0 \%$ of SL \\
Outer rostral barbel length & $19.8 \%-21.0 \%$ of head length & $9.4 \%-11.8 \%$ of head length \\
Maxillary barbel length & $28.6 \%-30.2 \%$ of head length & $15.3 \%-21.8 \%$ of head length \\
\hline
\end{tabular}

rakers 8 .

Body depth 16.2-16.3 (mean: 16.3) \% of SL, head length $24.1 \%-24.8$ (24.5) \% f SL, length of caudal peduncle $17.6 \%-18.1$ (17.9) \% of SL, depth of caudal peduncle 8.1\%-9.6 (8.4) \% of SL, pre-dorsal length 56.7\%-57.4 (57.1) \% of SL. Head depth 65.4\%-67.1 (66.3) \% of head length, head width 53.9\%-56.0 (55.0) $\%$ of head length. Depth of caudal peduncle 45.9\%-53.2 (49.6) \% of length.

Body was small and compressed (Fig. 1). Head length was longer than body depth. Dorsal profile of the body was slightly convex and the ventral profile straight. Dorsal fin origin was nearer to the caudal fin base than to the tip of the snout, and in advance of pelvic fin origin; distal margin of dorsal fin was straight; tip of folded dorsal fin surpassing vertical of pelvic fin tip and nearly reaching to the vertical of anus. Distal margin of pectoral fin was slightly convex. In male, the first and second branched rays of the pectoral fin were slightly elongated. Tip of pectoral fin reached $55.7 \%-70.3 \%$ of distance between pectoral and pelvic fin origins. No auxiliary lobes at pectoral and pelvic fin bases. Pelvic fin origin was opposite to the base of first branched dorsal fin ray, tip of pelvic fin reached $66.4 \%-75.6 \%$ of distance between pelvic and anal fin origins, but not reaching to the anus. The anus was located immediately at the front of anal fin origin. Anal fin reached $69.1 \%-89.1 \%$ of length of caudal peduncle, distal margin was rounded. Caudal peduncle was elongated and compressed. Caudal adipose keel was underdeveloped. Distal margin of caudal fin was almost straight.

Head was elongated and compressed. Head length was larger than head width. Head depth was larger than head width and equal to body depth. The snout was fleshy and conical. Eyes were absent. Suborbital spin was weak, bifid, its length obviously shorter than the length of maxillary barbel. Nostrils close to each other, nearer to the base of the suborbital spin than to the tip of the snout. Anterior nostril forms a short tube. Mouth situated at ventral side of head. Upper lip is fleshy 
without any furrows or papillae. Each side of the lower lip was separated from the other by a longitudinal mental groove at the middle of the lower lip. Each side of the lower lip had a developed and fleshy mental lobe. The posterior margin of each mental lobe had two barbel-like protuberances. There were three pairs of barbels. Inner rostral barbel almost reached to the corner of the mouth, its length was $19.8 \%-21.0 \%$ of the head length, outer rostral barbel reached beyond the tip of the suborbital spine, its length was $28.6 \%-30.2 \%$ of the head length; maxillary barbell was very long and reached to the operculum, its length was $44.6 \%-46.0 \%$ of the head length. Lateral line was absent. Head was naked. Body was covered entirely in small scales except on the head and abdomen.

Gill rakers were short and blunt and widely arra-

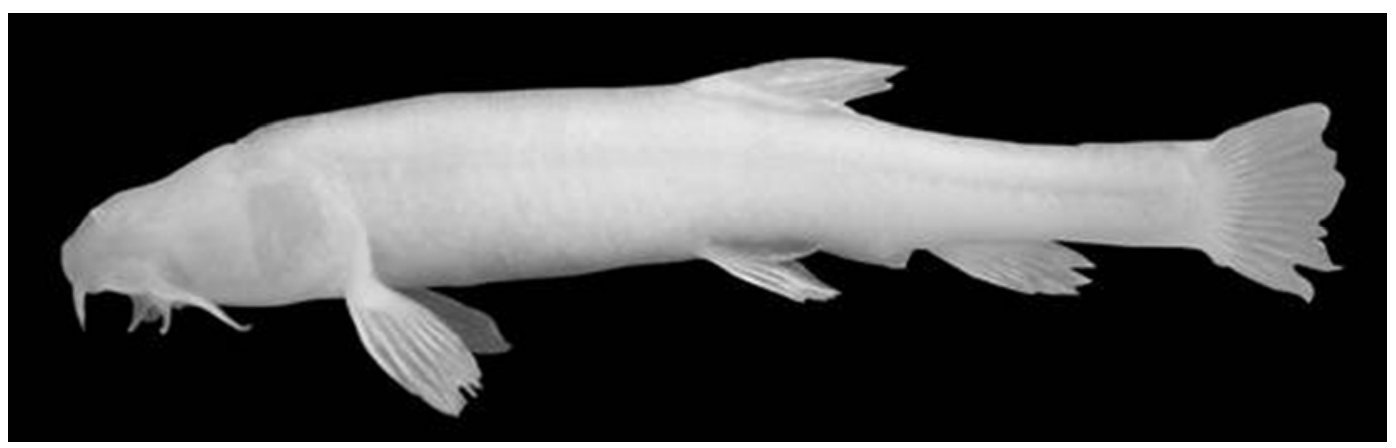

Fig. 1 Protocobitis polylepis, 060001, 33.0mm SL; Wuming, Guangxi

nged. Intestine was very simple and straight without loops. Posterior airbladder capsule was absent.

Sexual dimorphism. In the male, the first and second branched ray of the pectoral fin was slightly elongated and slightly more thickened than those in the female.

Colour pattern. Dorsal of head and side of body above lateral line was grayish with light pigment. Other

\section{Reference:}

Yang JX., Chen YR, Lan JH. 1994. Protocobitis typhlops, a new genus and species of cave loach from China (Cypriniformes: Cobitidae). Ichthyol. Explor[J]. Freshwaters, 5: 91-96. parts of the body were pale without pigment.

Distribution. Protocobitis polylepis has been known only from the locality where it was found, in an underground water source near the county town of Wuming, Guangxi.

Etymology. polylepis (Greek ), refers to the body being entirely covered by scales.
Chu XL, Chen YR et al. 1989. The fishes of Yunnan, China (part I Cyprinidae). Science Press, Beijing: 1-377. 